\title{
Capital budgeting under uncertainty: an empirical study
}

\author{
H.M.A. Parry and C. Firer* \\ Greduate School of Business Administration. University of the Witwatersr and, P.0. Box 98. Wits 2050. Republic of South Africa
}

Received 21 February 1990; accepted 19 March 1990

\begin{abstract}
The practices of and atitudes towards risk analysis in South African industrial companies is studied. Major findings are that few companies use the sophisticated methods of risk analysis recommended in the financial literalure; there is a wider use of quantitative techniques by the more capital intensive companies; there is general dissatisfaction with the application of these techniques in industry; companies perceive a neod for more use of quantitative risk-analysis techniques to aid decision-making. It is hoped that a greater understanding of the current practices of risk-analysis techniques and the attitudes of decision-makers will assist in the selection of appropriate capital budgeting methodologies to improve investment decisions made under uncertainty.
\end{abstract}

\begin{abstract}
Die praktyk van, en die houding leenoor risiko-analise in Suid-Afrikaanse nywerheidsmaalskappye word beswdeer. Die belangrikste bevindinge is dat min maatskappye gebnuik maak van die verfynde metodes van risikoanalise soos in finansiële literatuur bespreek; dat daar 'n groter toepassing is van kwantitatiewe tegnieke deur die meer kapitaalintensiewe ondernemings; dat daar algemene ontevredenheid oor die toepassing van die tegnieke heers; maatskappye besef die behoefte om in ' $n$ groter mate gebruik te maak van die kwantatiewe risikomelodes vir besluitneming. Daar word vertrou dat groter begrip van die lopende praktyk van risikoanalise en die houding van besluitnemers sal bydrae tot beter keuses van geskikte kapitaslbegrotingsmetodes om beleggingsbesluite te neem in onsekere omstandighede.
\end{abstract}

To whom all correspondence should be addressed.

\section{Introduction}

The environment in which company executives make business decisions has become increasingly turbulent and uncernain during the 1980 s. This has been particularly true in South Africa which has seen a growth in the importance of political and social issues in corporate decision-making. The long-term survival of companies depends on their ability to exploit new business opportunities, sustain profitable operations and divest of unprofitable assets. These activities involve imponant capital budgeting decisions which shape the future of the company.

The theory of finance has made available several quantitative techniques which have considerable potential in assisting decision-makers in dealing with the uncertainty sumounding such decisions. However researchers have observed that many companies are failing to use capital budgeting techniques that have become universally accepted by academics (Bierman, 1986, and Gitman and Forrester, 1977). Not all prospective projects are equally risky, and an important area in the theory describes how to incorporate risk into the capital investment appraisal process.

Ongoing research in the US and UK has had, as its goal, the evaluation of the extent to which firms are adopting risk-adjustment techniques in their analyses. However, very little is known about how South African companies cope with the risks of investing capital and to what extent they are aware of and use the quantitative rechniques available to them.

Thus the objectives of the research reported here are to establish and compare the awareness and use of riskanalysis tochniques in capital budgeting across South African industrial companies of differing capital invensity, to investigate the attitudes of decision-makers lowards these risk-analysis techniques and to assess their perceived noeds for methodologies to cope with uncertainty.

\section{Risk assessment and adjustment techniques}

While intuition is often used to evaluate the risk of a capital budgeting proposal, there are several formal techniques which can help in assessing risk. These include sensitivity analysis, decision trees, simulation and scenario analysis. A good understanding of these methods is very important if sound capital budgeting decisions are to be made by top executives.

Sensitivity analysis is used to determine which of the input variables are critical to the success of the project. All such variables are flexed by a given amount, and the relative impact of the flexing on the project's Net Present Value (NPV) or Internal Rate of Retum (IRR) calculated. The technique suffers from the problem that changes in variables are considered in isolation, but it does provide useful insights into project riskiness.

Scenario analysis, in addition to measuring the sensitivity of changes in key variables, also looks at the range of likely values of these variables. Usually worst and best case values are used to produce estimates of the worst and best possible outcomes. Assigning probabilities to these outcomes, as well as to the expected outcome, allows for the calculation of an expected NPV and its associated standard deviation.

The fact that only a few discrete outcomes are produced limits the value of scenario analysis. The wellknown technique of Monte Carlo simulation (Hert, 1964) is a more rigorous method of assessing a project's stand-alone risk. It ties together sensitivities and input variable probability distributions, and requires the use of a computer and fairly sophisticated software. The output is an NPV probability distribution, the standard deviation of which is a measure of project risk. 
Decision-tree analysis is generally used in conjunction with projects that require capital outlays over several years (Brigham, 1988: 331) and provides estimates of expected NPV and the concomitant standard deviation.

The four methods outlined above are designed to provide an assessment of the relative riskiness of a project. Once management has a reasonable 'feel' for the level of risk involved in an investment proposal, it must be incorporated into the capital budgeting decision criteria. There are two fundamental ways in which the adjustment can be made. Firstly, the hurdle rate for project acceptance can be changed by a suitable premium, or discount, to allow for risk that is different from the 'normal' level accepted by the company. Secondly, the estimated cash flows can be adjusted to allow for changing levels of risk over the life of the project.

The hurdle rate to be adjusted to account for risk will depend on which capital budgeting method is used. The two popular methods for risk adjustment are maximum payback period and the risk-adjusted discount rate.

If a project has been assessed to have risk that is higher than normally acceptable for the company, the maximum payback period may be shortened. However, the payback method on its own cannot effectively deal with risk, as it only acts as a constraint on the timing of cash inflows and does not consider the variability of those inflows. All results beyond the payback period are ignored, though these may be the most difficult to forecast and may thus carry the most risk. The adjustment of the maximum payback period, although simple and readily understandable, should be regarded as a crude method which attempts to avoid a loss situation. The method should only be used as a supplementary capital budgeting tool together with more sophisticated techniques.

The technique known as the risk-adjusted discount rate involves changing the hurdle rate if the intemal rate of retum is used or the discount rate if the net present value or profitability index is used. Determining how much to adjust the discount rate for different levels of risk is a difficult task. If the anticipated risk of a project is equal to the risk class of the firm, the cost of capital (which includes a risk factor) is the appropriate discount rate. If the proposed project has been assessed to be more or less risky than the risk class of the firm, the rate of discount should be adjusted up or down from the cost of capital because the discount rate should reflect the riskiness of the cash flows being discounted.

It may be convenient to use a risk classification system for projects, each class of investment having a discount rate appropriate for its risk. Projects involving contractual or legal obligations may be low risk and require a discount rate below the cost of capital. Ongoing projects involving existing business operations may require the firm's cost of capital as the discount rate. Investments into new products and markets may require a risk premium of five to ten per cent above the firm's present cost of capital to account for the uncertainty of customer and competitor reaction, learning curve effects, advertising expenses, price levels, etc. Research and development projects are usually quite risky and are likely to require a substantial risk premium.

The risk-adjusted discount rate method has a number of limitations. In using a constant risk-adjusted discount rate in the calculation of net present value, it is assumed that the risk of achieving future expected cash flows remains the same over the life of the project. This may not be realistic, particularly if the project involves the introduction of a new product. In this case it may be expected that the major risk occurs during the early years while the product is developed, marketed and promoted. The risk-adjusted discount rate should therefore decrease over time rather than remaining constant.

The risk of a project may only apply to the initial capital cost of the plant during the engincering, construction and commissioning stages. Raising the discount rate for future revenues which may be relatively certain is a poor way to adjust for the risk related to the cost of the plant.

Another weakness of the risk-adjusted discount rate is that it does not tell decision-makers which risks they are taking. Theoretically, a risk-free rate should be used to discount for the time value of money, and adjustments for any risks should be made separately.

There are two principal methods which account for risk by adjusting the project's cash flows, namely project life adjustment and the certainty equivalent approach.

Project life adjustment involves the truncation of cash flows by reducing the project life and hence the apparent return in order to account for risk. The technique is criticised by Van Horne (1976) because there is already an uncertainty element in project life and no consideration is given to the other variables which affect the probability distribution of the profitability measure (i.e. the essence of risk). The method is subjective, crude and grossly inferior to other more sophisticated techniques.

A valid alternative to adjusting the discount rate is to first reduce each expected cash flow to its certaintyequivalent and then discount for time using the risk-free rate. An appropriate risk-free rate would be the return expected on Treasury Bills. This involves determining what certain return the decision-maker would be willing to take in place of each year's uncenain retum. For example, assume that the expected return in year ' $t$ ' is R5000. The decision-maker may indicate that he is indifferent between receiving an uncertain R5000 and a certain R3000. The R3000 is the certainty-equivalent and represents a riskless retum. The certainty-coefficient, which increases as risk decreases and has a value between zero and one, is equal to 0,60 (R3000/R5000). Certainty-coefficients are determined for each year's cash flow and the net present value calculated using the formula:

$$
\begin{aligned}
& N P V=\sum_{i=0}^{n} \frac{x_{1} c_{t}}{(1+i)^{t}} \\
& c \quad=\text { Expected net cash flow in period } t
\end{aligned}
$$


$x_{1}=$ Certainty-coefficient for period $t$

i $=$ Risk-free rate (after tax)

n $\quad=$ Project life

The NPV decision rule remains unchanged, i.e. a project should be accepted if the NPV is positive.

The certainty-equivalent approach is theoretically sound and avoids many of the objections related to adjusting the discount rate. The degree of risk adjustment can be decided by management for each time period and the method also disaggregates the discounting for time and the adjusting for risk. Despite its advantages the use of the certainty-equivalent method raises implementation problems in that decision-makers may find it easier to subjectively raise the discount rate for a risky project rather than to specify certaintyequivalents for each year.

\section{Prior research}

Over the past two decades numerous studies have been conducted around the world to study capital budgeting practice (eg. Petry, 1975; Petty, Scott and Bird, 1975; Gitman and Forrester, 1977; Schall, Sundem and Geijsbeek, 1978; Kim and Farragher, 1981; Butler, 1982; Stanley and Block, 1983; Bierman, 1986; Linneman and Klein, 1985; Pike and Sharp, 1989).

The results indicate that companies use more than one technique with internal rate of return and payback being the most popular. There is a strong preference for the use of IRR as the primary technique: the study by Stanley and Block (1983) indicating a 65\% usage. They report a trend over time away from the less sophisticated return on investment method and towards increased use of IRR as the primary method. A study by Pike and Sharp (1989) in the United Kingdom found that $75 \%$ of firms use IRR, this percentage having grown from $44 \%$ in 1975.

The most popular secondary or supplementary technique was shown by many surveys to be payback period, with usage ranging from $38 \%$ to $44 \%$. The use of net present value as a secondary method was reported as $26 \%$ by Gitman and Forrester (1977) and 30\% by Stanley and Block (1983).

Petry (1975) focused on the use of capital budgeting tools according to the size of firm and type of industry. Although he found no definite pattern to be discemible in terms of the use of the techniques in different industries he did conclude that:

'the capital intensive industries seem to prefer the time-weighted measures - discounted rate of return and net present value - and the less capital intensive firms prefer payback'.

He also observed that highly capital intensive companies that are more capital intensive tend to use a greater number of different capital budgeting techniques.

Kim and Farragher (1981) found that firms in 'technologically-oriented' industries tend to be more advanced in the use of sophisticated capital budgeting practices.

Work by Peuty, et al. (1975) and Schall, et al. (1978), indicated that the weighted average cost of capital is used as a discount rate by $30 \%$ and $46 \%$ of firms respectively. A wide variety of methods is used with the most popular method in the earlier study being a management determined target rate of return. A significant number of firms (17\% and $26 \%$ ) prefer to use the cost of a specific source of funds as a discount rate.

Several researchers (Petry, 1975; Gitman and Forrester, 1977; Schall, et al. 1978 and Butler, 1982) found that most companies give explicit consideration to risk and uncertainty when making capital budgeting decisions. Their studies indicated that $70 \%$ to $80 \%$ of firms make some form of risk adjustment. Schall, et al. (1978) reported that although only $36 \%$ of the responding firms used a quantitative risk-assessment technique, $78 \%$ had specific methods of adjusting for risk.

The question of how firms adjusted for risk was also investigated by Petry (1975), Petty, et al. (1975), Gitman and Forrester (1977) and Butler (1982). The risk adjusted discount rate was generally found to be the most popular technique but Petty, et al. (1975) found that a surprisingly large $77 \%$ of firms used an adjustment of the payback period as a method of accounting for risk. This method was reported by Butler (1982) to be the second most popular technique with $42 \%$ usage by respondents. These two results are in contrast to the fairly low usage of adjusted payback found by both Petry (1975) and Gitman and Forrester (1977).

A large fraction of South African firms (36\%) uses subjective judgement when adjusting for risk (Butler 1982). This is significantly higher than that found by the American researchers and suggests a lower sophistication in capital budgeting under uncertainty for South African companies. This conclusion is supported by the difference in use of the certainty-equivalents approach by American and South African firms; $26 \%$ in the United States versus $18 \%$ in South Africa.

Petty, et al. (1975) sought additional information from respondents in an attempt to discover the extent to which diversification is used to reduce risk. Altogether $57 \%$ of the respondents answered no to the question:

'Is diversification of corporate investments (in order to reduce risk) an important capitalbudgeting objective of your firms?'

Thus there seems to be a difference of opinion between corporate decision-makers and academics with regard to the importance of portfolio diversification as a practical risk-reduction technique.

In a recent survey by Bierman (1986), information was obtained from senior financial officers of some of the largest American companies, relating to difficulties encountered in implementing capital budgeting techniques. Most of the comments reflected difficulties experienced in coping with uncertainty and the major conclusion drawn was that a gap existed between the needs of decision-makers and the methods currently being used for evaluating capital investments. This gap seemed to be particularly significant in the area of risk analysis. 


\section{The research question}

If financial theory is to be correctly applied in capital budgeting, the issue of the incorporation of risk analysis into capital budgeting is one of fundamental importance.

This study addresses the question of how South African companies cope with the risks of investing capital and to what extent they are aware of and use the quantitative techniques available to them. It also investigates whether there is a 'difference in capital budgeting practice adopted by companies of different capital intensity. A survey of the practices and attitudes of decision-makers across companies of different capital intensity will, it is hoped, help to identify appropriate methodologies for dealing with uncertainty. The following hypotheses were tested:

\section{Hypothesis 1}

'The methods most commonly used to analyse the risks of capital investment projects are relatively subjective and unsophisticated compared with modern available methods.'

\section{Hypothesis 2}

'There is a greater use of quantitative risk-analysis techniques in more capital intensive companies.'

\section{Hypothesis 3}

'There is a greater concern about risks specific to the investment project being considered (unsystematic risk) in the more capital intensive companies.'

\section{Hypothesis 4}

'Decision-makers are dissatisfied with the available methods for risk analysis. More specifically, the perceptions are that:

(i) The methods are too complex and academic and therefore impractical.

(ii) The methods are too costly and time-consuming.

(iii) Decision-makers are not sufficiently skilled in the use of the methods to fully benefit from them.'

\section{Hypothesis 5}

'There is a need by decision-makers for the use of more quantitative and sophisticated approaches for evaluating capital investment projects under uncertainty.'

\section{Methodology}

A questionnaire was sent to the financial director of each of the 270 industrial companies listed on the Johannesburg Stock Exchange. In order to keep the questionnaire length and complexity to a reasonable level, the research issues were kept relatively simple. The questionnaire was divided into four sections. The first section, entitled 'company background', was included to obtain information on the characteristics of the responding firms in terms of the business sector, asset size, capital budget size, growth rate and profitability.

Section two was designed as a brief inquiry into the capital budgeting practices used by the respondents, while the third section comprised the main body of the questionnaire and had the objective of establishing how companies dealt with risk and uncertainty when making capital budgeting decisions.

The final section contained seven questions intended to elicit information from respondents concerning their attitudes towards risk analysis. Four of the questions attempted to determine the extent of respondents' needs with regard to coping with uncertainty, and three questions probed the level of satisfaction of respondents concerning the available risk-analysis techniques.

Company financial statements were used to calculate capital intensity, which was defined as total assets divided by net sales. Average values for the past three years were used to classify companies into four categories of approximately equal size. These had capital intensity ratios of $0-0,50 ; 0,51-0,70 ; 0,71-0,85$; > 0,85 .

\section{Results}

Altogether 71 replies were received by the cutoff date of 8 December 1986. Of these 65 were usable, equivalent to a response rate of $24 \%$. In all four capital intensity groupings response rates were over $20 \%$.

A wide cross-section of companies were included in the sample of respondents. They had average total assets of R90 million and capital budgets ranging from R0,25 million to more than R500 million. There was a strong correlation between asset size and the magnitude of the capital budget.

Table 1 sets out the capital budgeting methods in use and their relation to capital intensity.

The average number of techniques used by each company was 2,9 indicating that decision-makers use a multi-technique approach to capital budgeting. This approach of not relying on a single technique could be an attempt by companies to cope better with uncertainty.

The most popular primary technique overall was internal rate of return (43\%) followed by retum on investment (32\%). However, a pronounced difference between firms of high and low capital intensity in the use of a primary capital budgeting technique was found. $62 \%$ of high capital intensity firms prefer the IRR

Table 1 Capital budgeting methods in use

\begin{tabular}{lccc}
\hline & \multicolumn{3}{l}{ Cepital intensity } \\
\cline { 2 - 4 } Method & Low & High & Total \\
\hline & & & \\
Internal rate of retum & $64 \%$ & $76 \%$ & $69 \%$ \\
Net present value & $50 \%$ & $52 \%$ & $51 \%$ \\
Profitability index & $11 \%$ & $14 \%$ & $12 \%$ \\
Present value payback & $31 \%$ & $41 \%$ & $35 \%$ \\
Accounting payback & $56 \%$ & $59 \%$ & $57 \%$ \\
Retum on investment & $75 \%$ & $52 \%$ & $65 \%$ \\
Avernge number of methods & 2.9 & 2,9 & 2,9 \\
\hline
\end{tabular}


method compared with only $24 \%$ of low capital intensity firms. The most popular primary method for low capital intensity firms is return on investment $(47 \%)$. These results are a strong indication of lower sophistication in capital budgeting by companies of lower capital intensity.

The most popular secondary technique used by all respondents was accounting payback (36\%). This method was preferred as a supplementary technique by $35 \%$ of low capital intensity firms and 38\% of high capital intensity firms. This response is not surprising as the payback method can be considered to be a crude form of risk analysis and its popularity as a supplementary decision-making aid has prevailed for years.

Net present value was reported as being a primary technique by only $10 \%$ of the respondents and as a secondary technique by $22 \%$ of respondents. This method is therefore also considered by industrial practitioners to be of benefit mainly as a supplementary technique. This finding is in contrast to the generally accepted view that the NPV technique is superior to the other capital budgeting methods (Clark, Hindelang and Pritchard, 1984: 57-76).

Altogether $84 \%$ of the total respondents indicated that they use some form of discount rate when doing a capital budgeting analysis. The most popular basis for discounting is the use of the weighted average cost of capital (31\%). American researchers, Petty, et al. (1975) and Schall, et al. (1978) established that the weighted average cost of capital was used by $30 \%$ and $46 \%$ of their respondents respectively.

The next most commonly used discount rate is the inflation rate, which is used by $30 \%$ of respondents although there is little theoretical justification for its use. Possible reasons for its popularity could be that the inflation rate is conceptually simple to understand and forecasts of future rates are usually readily available.

The most significant difference between high and low capital intensity firms is in their use of the after-tax cost of debt, which was used as a discount rate by $32 \%$ of low capital intensity firms but by only $8 \%$ of high capital intensity firms. This could reflect a lack of sophistication by low capital intensity firms. The after-tax cost of debt is usually the least expensive source of funds for a company and if used as a discount rate, could lead to some projects being accepted in error.

Other discount rates used were a rate based on past experience (13\% of respondents) and a rate specified by a holding company (6\%).

It thus appears that a substantial proportion of responding companies are using discount rates which are theoretically incorrect. This probably results in suboptimal decision-making when considering capital investment projects using time-weighted evaluation techniques.

\section{Risk-analysis practices}

Respondents were asked to indicate what their firms understood by the term risk in the context of capital budgeting. Probability of not achieving a target retum was selected by $41 \%$ of the respondents, whereas $13 \%$ defined risk as the probability of making a loss. Both these definitions can be categorised as being associated with negative variation or semi-variance statistic (Copeland and Weston, 1983: 149). The majority of respondents (54\%) are therefore concerned with this downside risk and $22 \%$ defined risk as the variation in possible returns. Litule difference was noted between high and low capital intensity companies.

The study by Petty, et al. (1975) indicated that $40 \%$ of respondents defined risk as negative variance and $30 \%$ as total variance. It therefore appears that in 1986 South African industrial companies were more concerned with the downside risks of capital investments than the American respondents in the 1975 study.

$86 \%$ of companies in the high capital intensity stratum use quantitative methods when assessing risk compared with only $39 \%$ in the low capital intensity stratum.

Previous surveys in America by Petty and Bowlin (1976) and Schall, et al. (1978) indicated that the fractions of respondents using quantitative riskassessment techniques were $30 \%$ and $36 \%$ respectively. However it would be incorrect to deduce that South African companies make greater use of quantitative techniques, since the American studies were carried out ten years previously, and recent longitudinal studies have shown a trend towards the use of more quantitative techniques in the United States of America (Clark et al. 1984: 57-60).

Table 2 shows the responses to questions relating to the respondents familiarity with quantitative techniques for the assessment of risk.

It is evident that the most widely used technique for assessing uncertainty is sensitivity analysis with $61 \%$ of companies reporting some degree of use; $23 \%$ using the method sometimes and 38\% using it often. Only 5\% indicated that they are not familiar with this technique.

The second most popular technique is scenario analysis, used by $35 \%$ of companies, although only $15 \%$ use this technique often. A significant fraction of companies (at least $31 \%$ ) is not familiar with scenario analysis. The use of scenario analysis is more prevalent in America since $50 \%$ of firms investigated by Linneman and Klein (1985) reported using it.

Decision trees and Monte Carlo simulation are not at all popular as risk-assessment techniques with only $11 \%$ and $7 \%$ of respondents respectively reporting some

Table 2 Quantitative techniques for assessment of risk

\begin{tabular}{|c|c|c|c|c|c|}
\hline $\begin{array}{l}\text { Technique to } \\
\text { assess risk }\end{array}$ & $\begin{array}{l}\text { No } \\
\text { response }\end{array}$ & $\begin{array}{l}\text { No } \\
\text { familiar }\end{array}$ & $\begin{array}{l}\text { Familiar } \\
\text { but not } \\
\text { used }\end{array}$ & $\begin{array}{l}\text { Used } \\
\text { some- } \\
\text { times }\end{array}$ & $\begin{array}{l}\text { Used } \\
\text { often }\end{array}$ \\
\hline $\begin{array}{c}\text { Sensitivity } \\
\text { analysis }\end{array}$ & $17 \%$ & $5 \%$ & $17 \%$ & $23 \%$ & $38 \%$ \\
\hline Decision trees & $18 \%$ & $19 \%$ & $52 \%$ & $9 \%$ & $2 \%$ \\
\hline $\begin{array}{l}\text { Monic Carlo } \\
\text { simulation }\end{array}$ & $18 \%$ & $44 \%$ & $31 \%$ & $5 \%$ & $2 \%$ \\
\hline Scenario analysis & $17 \%$ & $31 \%$ & $17 \%$ & $20 \%$ & $15 \%$ \\
\hline
\end{tabular}


degree of use and only $2 \%$ reporting that they used these methods often. A large fraction of firms (44\%) reported that they are not even familiar with Monte Carlo simulation and $19 \%$ are not familiar with decision trees. Petty and Bowlin (1976) found in their survey that $30 \%$ and $37 \%$ of respondents use decision trees and simulation respectively. This is further evidence that South African companies are less sophisticated in capital budgeting than their American counterparts.

It can be concluded from the results of the research that very few firms use the more sophisticated methods available for risk assessment, namely, decision trees and Monte Carlo simulation. Sensitivity analysis is used reasonably widely but it is a relatively unsophisticated approach. The survey did not indicate any significant differences in the degree of familiarity or use of the four risk-assessment techniques across companies of different capital intensity.

Respondents were asked whether, having identified a project of risk different from the company average, they make a quantitative, subjective or no adjustment to their capital budgeting methodology. Only $3 \%$ made no adjustment, $34 \%$ used a subjective approach and $63 \%$ employed at least one quantitative technique. $79 \%$ of high capital intensity companies use quantitative techniques compared to only $50 \%$ of low capital intensity firms. American studies reported that $70 \%$ to $80 \%$ of firms make some form of quantitative risk adjustment.

The respondents were also asked to indicate whether they were familiar with or use six given risk-adjustment methods. The results are reported in Table 3.

The technique that is used often by most respondents $(32 \%)$ is an adjusted hurdle rate for the internal rate of return. In contrast a risk-adjusted discount rate is used often by only $14 \%$ of respondents. This would be expected given the higher use of IRR compared to NPV (see Table 1). $23 \%$ of respondents frequently adjust the hurdle rate for the accounting rate of return. Adjusting the maximum payback period is used often by only $9 \%$ of firms but used sometimes by $32 \%$ of firms. This result confirms the previous conclusion that payback period is considered to be more of a supplementary technique in capital budgeting.

Adjustment of project life was used by $25 \%$ of respondents and the use of certainty-equivalents was reported by $21 \%$ of firms. $31 \%$ of respondents were not familiar with certainty-equivalents although most were familiar with the other five risk-adjustment methods.

It can be concluded that there is a preference by nearly half of the responding firms for the use of relatively unsophisticated techniques of risk adjustment, namely, adjustment of hurdle rates for IRR and ROI. Approximately one third of firms use the risk adjusted discount rate to some extent. However, only one fifth of firms make some use of certainty-equivalents, which is the technique regarded as being superior and the most sophisticated as an aid to risk adjustment (Clark, et al. 1984: 176-193). The certainty-equivalents method was reported by Butler (1982) to be used by only $18 \%$ of
Table 3 Quantitative techniques for adjustment for risk

\begin{tabular}{|c|c|c|c|c|c|}
\hline $\begin{array}{l}\text { Technique } \\
\text { to adjust } \\
\text { for risk }\end{array}$ & $\begin{array}{l}\text { No } \\
\text { response }\end{array}$ & $\begin{array}{l}\text { Not } \\
\text { familiar }\end{array}$ & $\begin{array}{l}\text { Farniliar } \\
\text { but not } \\
\text { used }\end{array}$ & $\begin{array}{l}\text { Used } \\
\text { some- } \\
\text { limes }\end{array}$ & $\begin{array}{l}\text { Used } \\
\text { often }\end{array}$ \\
\hline $\begin{array}{l}\text { Risk adjusted } \\
\text { discount rate }\end{array}$ & $22 \%$ & $6 \%$ & $37 \%$ & $22 \%$ & $14 x$ \\
\hline $\begin{array}{l}\text { Intermal rate of } \\
\text { retum hurdle rate }\end{array}$ & $17 \%$ & $5 \%$ & $25 \%$ & $22 \%$ & $32 \%$ \\
\hline $\begin{array}{l}\text { Retum on investment } \\
\text { hurdle rate }\end{array}$ & $18 \%$ & $3 \%$ & $31 \%$ & $25 \%$ & $23 x$ \\
\hline $\begin{array}{l}\text { Maximum payback } \\
\text { period }\end{array}$ & $20 \%$ & $5 \%$ & $34 \%$ & $32 \%$ & $9 \%$ \\
\hline Project life & $16 \%$ & $6 \%$ & $43 \%$ & $20 \%$ & $5 \%$ \\
\hline Certainty-equivalents & $23 \%$ & $31 \%$ & $25 \%$ & $12 \%$ & $9 x$ \\
\hline
\end{tabular}

responding companies, and this finding lends support to the above conclusion.

No significant differences were found concerning the familiarity and use of specific quantitative techniques for high or low capital intensity firms. However, firms of higher capital intensity clearly place more reliance on the use of quantitative risk-adjustment methods than on subjective adjustment.

In order to provide some additional insights into how companies cope with uncertainty, respondents were asked to indicate to what extent diversification was considered as part of their capital budgeting objectives.

Altogether $46 \%$ of the respondents did not regard portfolio diversification as an important risk-reduction technique, and this reflects a difference of opinion between corporate decision-makers and academics. A similar observation was made by Petty, et al. (1975) who found that $57 \%$ of respondents were uncertain about the desirability of having a diversification objective in order to reduce risk.

\section{Attitudes to risk analysis}

Respondents were asked to indicate their degree of agreement or disagreement to each of seven statements concerning different aspects of risk analysis. There was general agreement that decision-makers are not sufficiently skilled in the use of sophisticated riskanalysis techniques to benefit from them.

However, respondents neither agreed nor disagreed, but expressed neutrality when presented with the statements that sophisticated risk-analysis techniques are too costly and time consuming to be justified, and that they are too complex and academic to be of real practical use. Whilst it was difficult to draw any general conclusions from these responses, they may well be indicative of a general lack of understanding of advanced risk-analysis techniques.

High capital intensity companies felt that decision makers are given enough information on the uncertainty of capital investment proposals, whereas the respondents from companies with low capital intensity disagreed. 
All firms felt that there was a need for more quantitative approaches to coping with uncertainty, although the feeling was stronger amongst the capital intensive firms. However, all respondents indicated that entrepreneurial skills and judgement remained an important part of the process, despite the need for a quantitative approach.

Finally firms, especially those in capital intensive industries, disagreed with the proposition that, because even the most sophisticated of techniques cannot predict the future, they should not be used.

\section{Conclusions}

Hypothesis 1 is confirmed. Approximately one third of the respondents do not use any quantitative technique to assess risk or adjust for it. Of the remainder, almost all use the relatively unsophisticated sensitivity analysis. Few firms use a sophisticated method for risk adjustment.

The greater use of quantitative risk-analysis tools by more capital intensive firms confirms hypothesis 2.

Altogether $80 \%$ of high capital intensity firms regard unsystematic risk as very important, and most aim to achieve a degree of diversification in order to reduce risk. Hypothesis 3 is thus also confirmed.

Parts (i) and (ii) of hypothesis 4 could not be confirmed, but firms did indicate that a lack of skills precluded them from fully benefiting from techniques for risk analysis, thus confirming part (iii).

In confurming hypothesis 5 , companies did indicate a need for more quantitative techniques to be used by decision-makers. These views were more strongly held by those firms with high capital intensities, but respondents tempered this view with the need for complimentary entrepreneurial skills and judgement.

A major finding of this research is that very few companies appear to use sophisticated capital budgeting techniques. Although most of the high capital intensive companies use the internal rate of retum as a primary method, the low capital intensive companies clearly prefer to use the accounting rate of retum. The most popular secondary capital budgeting method is the payback period which is considered to be relatively crude and unsophisticated. The frequent use of sophisticated risk-analysis techniques is also limited to a small minority of companies. However, the research results indicate a wider use of quantitative risk-analysis techniques by the more capital intensive companies. There also appears to be general dissatisfaction with the application of these techniques in industry. Most companies nevertheless perceive a need for greater use of quantitative risk-analysis techniques to aid decisionmaking.

\section{References}

Bierman, H. 1986. Implementation of capital budgeting techniques. Tampa, Florida: Financial Management Association.

Brigham, E.F. \& Gapenski, L.C. 1988. Financial management. 5th Ed. Hinsdale, Ilinios: Dryden Press.

Butler, F.D. 1982. Criteria for major investment decisions. Johannesburg: University of the Witwatersrand (Unpublished MBA Research Report).

Clark, J.J., Hindelang, T.J. \& Pritchard, R.E. 1984. Capital budgeting. 2nd Ed. Englewood Cliffs, New Jersey: Prentice-Hall Inc.

Copeland, T.E. \& Weston F.J. 1983. Financial theory and corporate policy. 2nd Ed. Reading, Massachusetts: Addison-Wesley.

Gitman, LJ, \& Forrester, J.R. 1977. A survey of capital budgeting techniques used by major U.S. firms. Financ. Manage. Fall: 66-71.

Hertz, D.B. 1964. Risk analysis in capital investment. Harv. Bus. Rev., January-February: 95-106.

Kim, S.K. \& Farragher, E.J. 1981. Current capital budgeting practices. Manage. Acc., June: 26-30.

Linneman, R.E. \& Klein, H.E. 1985. Using scenarios in strategic decision making. Bus. Horiz., January-February: 64-74.

Petry, G.H. 1975. Effective use of capital budgeting tools. Bus. Horiz., October: 57-65.

Petty J.W. \& Bowlin, O.D. 1976. The financial manager and quantitative decision models. Financ. Manage., Winter: $32-41$.

Petty, J.W., Scoth, D.F. \& Bird, M.M. 1975. The capital expenditure decision-making process of large corporations. Eng. Econ., Vol. 20, 3: 159-172.

Pike, R. \& Sharp, J. 1989. Trends in the use of management science techniques in capital budgeting. Managerial and Decision Economics, 10: 135-140.

Schall, L.D., Sundem, G.L. \& Geijsbeek, W.R. 1978. Survey and analysis of capital budgeting methods. J. Fin., Vol 33, 1: 281-287.

Stanley, M. \& Block, S. 1983. An empirical study of management and financial variables influencing capital budgeting decisions for multinational corporations in the 1980s. Manage. Int. Rev., Vol 23, 3: 61-72.

Van Horne, J.C. 1983. Financ. Manage. and Pol., 6th Edition. Englewood Cliffs, New Jersey: Prentice-Hall Inc. 